\title{
The warming Tibetan Plateau improves winter air quality in the Sichuan Basin, China
}

\author{
Shuyu Zhao ${ }^{1}$, Tian Feng ${ }^{2}$, Xuexi Tie ${ }^{1,3}$, and Zebin Wang ${ }^{4}$ \\ ${ }^{1}$ Key Laboratory of Aerosol Chemistry and Physics, SKLLQG, Institute of Earth Environment, \\ Chinese Academy of Sciences, Xi'an, 710061, China \\ ${ }^{2}$ Department of Geography and Spatial Information Techniques, Ningbo University, Ningbo, 315211, China \\ ${ }^{3}$ Center for Excellence in Urban Atmospheric Environment, Institute of Urban Environment, Chinese Academy of Sciences, \\ Xiamen, 361021, China \\ ${ }^{4}$ Northwest Air Traffic Management Bureau, Civil Aviation Administration of China, Xi'an, 712000, China
}

Correspondence: Xuexi Tie (tiexx@ieecas.cn)

Received: 29 February 2020 - Discussion started: 31 March 2020

Revised: 10 October 2020 - Accepted: 22 October 2020 - Published: 3 December 2020

\begin{abstract}
Impacts of global climate change on the occurrence and development of air pollution have attracted more attention. This study investigates impacts of the warming Tibetan Plateau on air quality in the Sichuan Basin. Meteorological observations and ERA-Interim reanalysis data reveal that the plateau has been rapidly warming during the last 40 years (1979-2017), particularly in winter when the warming rate is approximately twice as much as the annual warming rate. Since 2013, the winter temperature over the plateau has even risen by $2{ }^{\circ} \mathrm{C}$. Here we use the WRF-Chem model to lay emphasis on the impact of the $2{ }^{\circ} \mathrm{C}$ warming on air quality in the basin. The model results show that the $2{ }^{\circ} \mathrm{C}$ warming causes an enhanced easterly wind, an increase in the planetary boundary layer height (PBLH) and a decrease in the relative humidity (RH) in the basin. Enhanced easterly wind increases $\mathrm{PM}_{2.5}$ transport from the basin to the plateau. The elevated PBLH strengthens vertical diffusion of $\mathrm{PM}_{2.5}$, while the decreased $\mathrm{RH}$ significantly reduces secondary aerosol formation. Overall, $\mathrm{PM}_{2.5}$ concentration is reduced by $17.5 \%\left(\sim 25.1 \mu \mathrm{g} \mathrm{m}^{-3}\right)$, of which the reduction in primary and secondary aerosols is 5.4 and $19.7 \mu \mathrm{g} \mathrm{m}^{-3}$, respectively. These results reveal that the recent warming plateau has improved air quality in the basin, to a certain extent mitigating the air pollution therein. Nevertheless, the climate system is particularly complicated, and more studies are needed to demonstrate the impact of climate change on air quality in the downstream regions as the plateau is likely to continue warming.
\end{abstract}

\section{Highlights}

- The Tibetan Plateau is rapidly warming, and the temperature has risen by $2^{\circ} \mathrm{C}$ from 2013 to 2017 .

- A warming plateau leads to an enhanced easterly wind, an increased PBLH and a decreased RH in the Sichuan Basin.

- The $2{ }^{\circ} \mathrm{C}$ warming significantly reduces $\mathrm{PM}_{2.5}$ concentration in the basin by $25.1 \mu^{-3} \mathrm{~m}^{-3}$, of which secondary aerosol is $19.7 \mathrm{\mu g} \mathrm{m}^{-3}$.

\section{Introduction}

The Tibetan Plateau is known as the third pole because of its high altitude and large area. It is also regarded as an important response region to the Northern Hemisphere and even global climate due to its sensitivity to climate change. Previous studies on the Tibetan Plateau show that the region was experiencing warming in the second half of the 20th century, especially in the winter months (Kuang and Jiao, 2016; Liu and Chen, 2000; Rangwala et al., 2009). The warming plateau not only plays a significant role in driving the weather and climate change, as well as the ecological system, but also has an important impact on air quality in the downstream regions. Xu et al. (2016) suggest that the thermal anomaly over 
the Tibetan Plateau obviously increases haze frequency and surface aerosol concentration in central-eastern China.

However, the impacts of climate change on air quality in China are still unclear. Some research has shown that climate change induced by greenhouse gas emission increases severe haze occurrence and intensity in winter in Beijing, and its impact will continue in the future (Cai et al., 2017; Zou et al., 2017). Similarly, Xu et al. (2017) suggest that the climate warming anomaly in the lower and middle troposphere over the continent around the Yangtze River Delta has led to more haze days in winter during recent decades. Conversely, another opinion suggests that climate change in the past 2 decades has been favorable for air pollution dispersion in northern China via enhancing mid-latitude cold surges in winter (Zhao et al., 2018). If cold surge is strong enough, pollutants would be transported to the downstream regions, causing better air quality in the upstream region but worse air quality in the downstream region. Thus, there may be regional differences in the impact of climate change on air quality.

Previous studies on air pollution in China are concentrated in the developed regions, such as the North China Plain, the Yangtze River Delta and the Pearl River Delta. Few studies have paid attention to the Sichuan Basin, although the region is undergoing severe air pollution, and mean $\mathrm{PM}_{2.5}$ concentration is more than $110 \mu \mathrm{g} \mathrm{m}^{-3}$ in winter (Qiao et al., 2019; Tao et al., 2017; Wang et al., 2018; Yang et al., 2011). Thus, it is necessary to explore the underlying causes that lead to air pollution in the Sichuan Basin.

The Sichuan Basin locates in the downstream region of the Tibetan Plateau, and its weather conditions are obviously affected by the plateau (Duan et al., 2012; Hua, 2017; Zhao et al., 2019). For instance, the foggy weather, southwest vortex and low-level shear line over the basin are closely associated with the plateau (Zhu et al., 2000). These changes in weather conditions induced by the plateau undoubtedly affect the development and dispersion of air pollution in the basin, because the huge terrain can trigger a thermodynamic forcing, which is of great importance for weather conditions in the surrounding regions (Bei et al., 2016; 2017; Zhao et al., 2015).

This study therefore focuses on how climate change on the Tibetan Plateau has affected air quality in the Sichuan Basin in recent years. Section 3 analyzes the temperature change on the plateau in the past 4 decades and especially emphasizes the change in the last 5 years. In Sect. 4, we design three sets of numerical simulations to calculate the impact of temperature change on air quality. One group includes two baseline simulations in two periods (January 2014 and January 2018), which are constrained by observed surface meteorological parameters and pollutant concentrations. The second group includes three sensitivity simulations during the 2013/14 winter, which uses the same emission inventory and meteorological fields as the baseline simulation in January 2014 except for a changed air temperature. We also set the third sensitivity simulation, in which the plateau is also warming, but on the basis of the period for the 2017/18 winter. We compare the difference in $\mathrm{PM}_{2.5}$ concentrations in these cases, and we also calculate differences in meteorological parameters that include winds (wind speed and direction), air temperature and relative humidity ( $\mathrm{RH})$, as well as the planetary boundary layer height (PBLH). Based on the differences in $\mathrm{PM}_{2.5}$ concentration and meteorological parameters above, we finally explain the cause-effect relationship between a warming plateau and changes in the winds, PBLH and RH in the Sichuan Basin. Moreover, we calculate the effect of the relationship on air quality in the basin.

\section{Data and methods}

\subsection{Observations}

To ensure a robust result, we use two datasets of surface air temperature in this study. One is the European Centre for Medium-Range Weather Forecasts (ECMWF) ERAInterim monthly mean reanalysis data (1979-2018), obtained from the website http://apps.ecmwf.int/datasets/ (last access: 1 December 2020), with the finest horizontal resolution of $0.125^{\circ} \times 0.125^{\circ}$. The other is hourly and monthly mean weather station observations from the National Oceanic and Atmospheric Administration (NOAA), available from http://gis.ncdc.noaa.gov/map/viewer/\#app=clim\& $\mathrm{cfg}=$ cdo\& theme $=$ hourly $\&$ layers $=1 \&$ node $=$ gis (last access: 1 December 2020).

Figure 1 shows the distribution of weather stations over the Tibetan Plateau, and these weather stations widely cover the entire plateau. Trends of annual mean and winter surface air temperature over the plateau are analyzed, and the winter is averaged over 3-month periods (December-JanuaryFebruary). Additionally, we use ambient air quality data to validate the model performance. Since 2013, the data have been released by the Ministry of Environmental Protection, China at http://www.aqistudy.cn/ (last access: 1 December 2020), including hourly $\mathrm{PM}_{2.5}, \mathrm{CO}$ and $\mathrm{O}_{3}$ mass concentrations. The monitoring stations for air quality are also shown in Fig. 1.

\subsection{Model configuration and experiments}

A state-of-the-art regional dynamical and chemical model (WRF-Chem model) is used in the study. Ideally, this study should set the Tibetan Plateau and the Sichuan Basin as the center of the model domain. However, considering the domain is too large, beyond the capability of our computer, we have to reduce the model domain. Nonetheless, to better simulate the atmospheric circulation over the plateau and its impact on air quality in the Sichuan Basin, we set the central location of the model domain at $32.2^{\circ} \mathrm{N}, 95.0^{\circ} \mathrm{E}$ over the plateau, and the simulation domain covers the $\mathrm{Ti}$ betan Plateau and the Sichuan Basin (Fig. 1). The Tibetan 


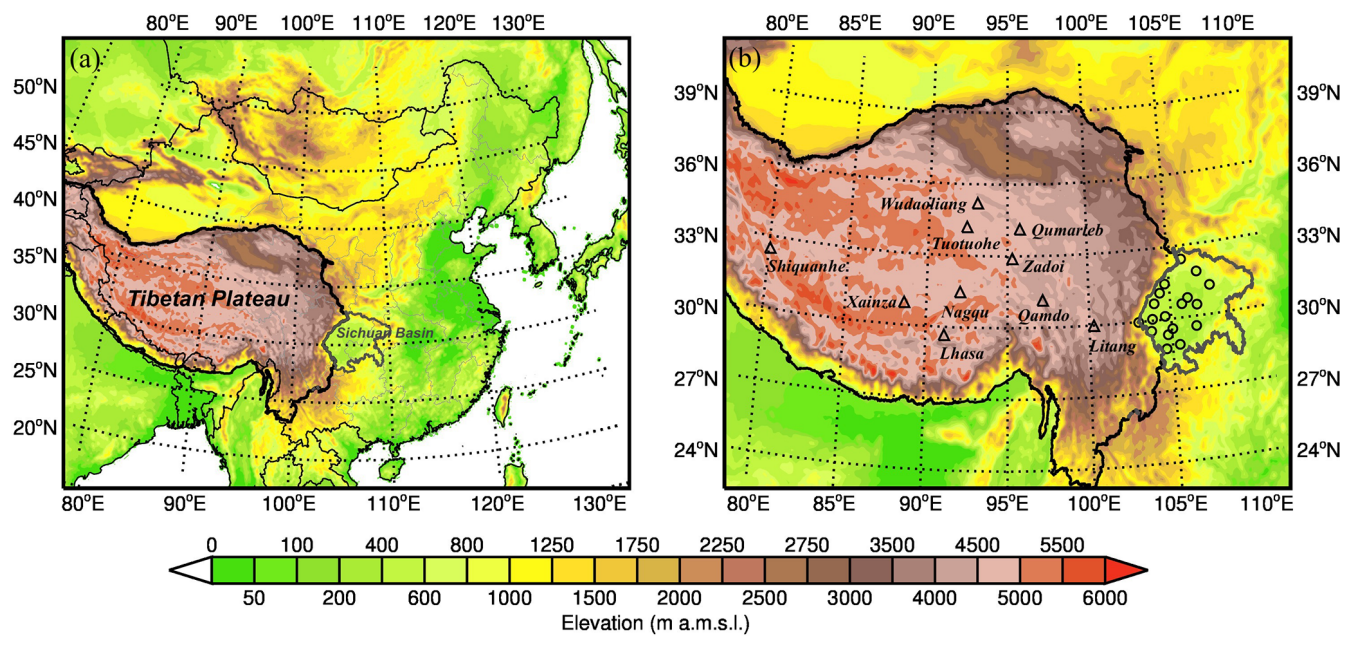

Figure 1. (a) Location map of the Tibetan Plateau (the region surrounded by the dark line) and the Sichuan Basin (the region surrounded by the gray line). (b) The model domain and the distribution of weather stations are marked as the triangles over the Tibetan Plateau, and air quality stations are marked as the circles over the Sichuan Basin.

Plateau covers about 2.5 million $\mathrm{km}^{2}$, with the averaged elevation of $4500 \mathrm{~m}$, and the Sichuan Basin covers about 0.16 million $\mathrm{km}^{2}$, with the elevation in the center of the basin less than $1000 \mathrm{~m}(250-700 \mathrm{~m})$. The model is set by a horizontal grid resolution of $9 \mathrm{~km}(451 \times 221$ grids), with 35 vertical sigma levels. The model description in detail is seen by Grell et al. (2005). The evaluation of the model performance has been conducted by many previous studies ( $\mathrm{Li}$ et al., 2011a; Tie et al., 2009, 2007). In this study, we use the Goddard longwave and shortwave radiation parameterization (Dudhia, 1989), the WRF single-moment (WSM) sixclass graupel microphysics scheme (Hong and Lim, 2006), the Mellor-Yamada-Janji (MYJ) planetary boundary layer scheme (Janjicì, 2002), the unified Noah land-surface model (Chen and Dudhia, 2001) and the Monin-Obukhov surface layer scheme (Janjicì, 2002). For chemical schemes, we use a new flexible gas-phase chemical module and the Community Multiscale Air Quality (CMAQ, version 4.6) aerosol module developed by the US EPA (Binkowski, 2003). Gas-phase atmospheric reactions of volatile organic compounds (VOCs) and nitrogen oxide $\left(\mathrm{NO}_{x}\right)$ use the SAPRC-99 (Statewide Air Pollution Research Center, version 1999) chemical mechanism. Inorganic aerosols use the ISORROPIA version 1.7, referring to Li et al. (2011a) and Feng et al. (2016). A SO heterogeneous reaction mechanism on aerosol surfaces involving aerosol water is added (G. Li et al., 2017), and $\mathrm{NO}_{2}$ heterogeneous reaction to produce $\mathrm{HONO}$ is also considered (Li et al., 2010). The secondary organic aerosol (SOA) calculation uses a non-traditional volatility basis-set approach by $\mathrm{Li}$ et al. (2011b). The photolysis rates are calculated by a fast tropospheric ultraviolet and visible (FTUV) radiation transfer model, in which the impacts of aerosols and clouds on the photochemistry processes are considered ( $\mathrm{Li}$ et al., 2011a; Tie et al., 2003, 2005). The wet deposition is calcu- lated by the method used in CMAQ and the dry deposition follows Wesely (1989).

We use the MIX anthropogenic emission inventory for the year of 2010, and it is available at the Multi-resolution Emission Inventory for China (http://www.meicmodel.org/ dataset-mix.html, last access: 1 December 2020), consisting of industrial, power, transportation and agricultural as well as residential sources (M. Li et al., 2017; Zhang et al., 2009). The emission inventory is constructed by a "bottomup" approach based on national and provincial activity data and emission factors. To improve the emission inventory accuracy, we use a "top-down" method here to constrain the emission inventory. We compare the simulated value with the measured value time and again until the simulations are close to the measurements. The biogenic emissions are calculated online by the Model of Emissions of Gases and Aerosols from Nature (MEGAN) (Guenther et al., 2006). Initial and boundary meteorological fields in the model are driven by $6 \mathrm{~h} 1^{\circ} \times 1^{\circ}$ NCEP (National Centers for Environmental Prediction) reanalysis data. Chemical lateral conditions are provided by a global chemistry transport model - MOZART (Model for OZone And Related chemical Tracers, version 4), with a $6 \mathrm{~h}$ output (Emmons et al., 2010; Tie et al., 2005). The spin-up time of the WRF-Chem model is $1 \mathrm{~d}$.

According to the meteorological records at weather stations, surface air temperature has risen by an average of $2{ }^{\circ} \mathrm{C}$ from 2013 to 2017 over the plateau (Table S1 in the Supplement). ERA-Interim reanalysis data also show that the troposphere $(600-250 \mathrm{hPa})$ over the plateau warmed during the 2013-2017 period, and the temperature increment shows a parabolic pattern with the altitude, by an average increase of $\sim 2{ }^{\circ} \mathrm{C}$ (Fig. S1 in the Supplement). Thus, we design several sensitivity simulations, with an average temperature increase in the troposphere over the plateau, to assess impacts of a 
warming plateau on air quality in the basin. To eliminate the influence of simulation background, we conduct two baseline simulations for the 2013/14 winter (January 2014) and the 2017/18 winter (January 2018) as the control groups. The other two sets focus on sensitivity simulations that reflect an observational increase in air temperature over the plateau. In 2014 , the sensitivity simulation uses the same emission inventory and meteorological conditions as the baseline simulation except that the temperature in the troposphere over the plateau increases by $0.5,1.0$ and $2.0^{\circ} \mathrm{C}$. The third group is a sensitivity simulation with an increase of $2.0^{\circ} \mathrm{C}$ on the basis of air temperature in January 2018. In the domain, we set the warming at all grids covering the plateau (the region surrounded by the dark line in Fig. 1b) in the initial and boundary fields. In order to ensure a persistent influence of the warming, we drive the initial field with $0.5,1.0$ and $2{ }^{\circ} \mathrm{C}$ increments every day in January 2014 and a $2{ }^{\circ} \mathrm{C}$ increment every day in January 2018 . Then, by comparing the difference between the sensitivity simulations and the baseline simulation, we determine the impact of the warming over the plateau on air quality in the basin.

\section{The warming Tibetan Plateau in the last 4 decades}

Figure 2 shows the variability and linear trend of surface air temperature at 10 weather stations over the Tibetan Plateau in winter during the last 4 decades (1979-2017). The winter mean temperature recorded from all the weather stations exhibits an obvious annual fluctuation and the linear regression shows a significant rising trend. Clearly, the plateau is continuously undergoing a warming phase, albeit with regional differences in the warming magnitude. The warming rates in different regions vary in the range of $0.5-1.0^{\circ} \mathrm{C}$ per decade. Compared with the warming rate of annual mean temperature (Fig. S2 in the Supplement), the warming rate in winter is approximately twice as much, suggesting that the warming in winter is more significant.

Using the ERA-Interim reanalysis data, Fig. 3 shows the temperature change during the same period (1979-2017). The result is consistent with weather records, showing that air temperature is significantly rising in most parts of the plateau. The maximal warming rate is around $0.6-0.8^{\circ} \mathrm{C}$ per decade, in the central and southern plateau. The warming in the other areas is slighter, with a rate of $0.3-0.6^{\circ} \mathrm{C}$ per decade. In particular, the averaged warming rate in the vast central plateau reaches about $1.0^{\circ} \mathrm{Cyr}^{-1}$ in the last 5 years (Fig. S3 in the Supplement), greater than the warming rate during the entire 40 years (Fig. 3). Both the observation records and reanalysis data evidently show that the plateau has been warming in the last 4 decades, and the warming trend for recent years is also more significant.

From the above temperature change analysis, we notice that there is obviously a positive temperature anomaly between 2013 and 2017 winters, implying an accelerating warming over the plateau. The observational temperature in winter increases by about $2{ }^{\circ} \mathrm{C}$ between 2013 and 2017 . Therefore, we assess the impact of a warming plateau on air quality in the Sichuan Basin.

\section{Results and discussion}

\subsection{Model validation}

To systemically evaluate the model performance on simulation $\mathrm{O}_{3}, \mathrm{CO}$ and $\mathrm{PM}_{2.5}$ mass concentrations, three statistical indices are used. They are the mean bias (MB), root-meansquare error (RMSE) and index of agreement (IOA). The calculation formulas are given in Text S1. The IOAs of air temperature and RH are 0.85 and 0.79 , respectively (Fig. S4a and $b$ in the Supplement), suggesting that the model captures the diurnal cycle of temperature and the variability of $\mathrm{RH}$ well. However, the calculated wind speed is overestimated, especially in the region between the Tibetan Plateau and the Sichuan Basin. This is because there is a dramatic elevation drop in the region, which makes it difficult for the model to replicate the observed wind speed and direction.

Figure 4 shows comparisons of hourly $\mathrm{O}_{3}, \mathrm{CO}$ and $\mathrm{PM}_{2.5}$ concentrations between the model simulations and measurements. The result shows that the simulated $\mathrm{CO}$ mean level is close to the measurement, with a $\mathrm{MB}$ of $0.11 \mathrm{mg} \mathrm{m}^{-3}$, indicating that the model reasonably reproduces the meteorological fields and long-range transport. Because the chemical lifetime of $\mathrm{CO}$ is relatively long ( $\sim$ months), the variability of $\mathrm{CO}$ is dominantly determined by the meteorological fields and atmospheric transport process. For the simulation of $\mathrm{O}_{3}$, in addition to the effects of meteorological fields and atmospheric transport process, its variability is strongly controlled by the photochemical process. The model result shows that the simulated diurnal cycle of $\mathrm{O}_{3}$ reasonably agrees with the measurement, with an IOA of 0.79 . There is only a small bias between the simulated and measured $\mathrm{O}_{3}$ mean concentration. The simulated $\mathrm{O}_{3}$ concentration is $1.7 \mu \mathrm{g} \mathrm{m}^{-3}$ higher than the measurement, suggesting that both the photochemistry and long-range transport capture the $\mathrm{O}_{3}$ variability in the region well. Finally, the IOA between the simulated and measured $\mathrm{PM}_{2.5}$ concentrations is 0.80 , indicating that the aerosol module in the model generally captures the measured $\mathrm{PM}_{2.5}$ variation.

However, there are some noticeable discrepancies between the simulations and the measurements. For instance, the simulated magnitude of $\mathrm{PM}_{2.5}$ concentration is larger than the measurement, and its mean level is underestimated by $13.1 \mu \mathrm{g} \mathrm{m}^{-3}$, less than $10 \%$ of the measurement $\left(\sim 153.5 \mu \mathrm{g} \mathrm{m}^{-3}\right)$. These discrepancies are likely due to the biases in the uncertainties in emission inventory and smallscale dynamical fields. During the period of 17 to 20 January, the observed wind speed concentrates in the range of $1-2 \mathrm{~m} \mathrm{~s}^{-1}$, with an average of $1.3 \mathrm{~m} \mathrm{~s}^{-1}$, while the simulated 

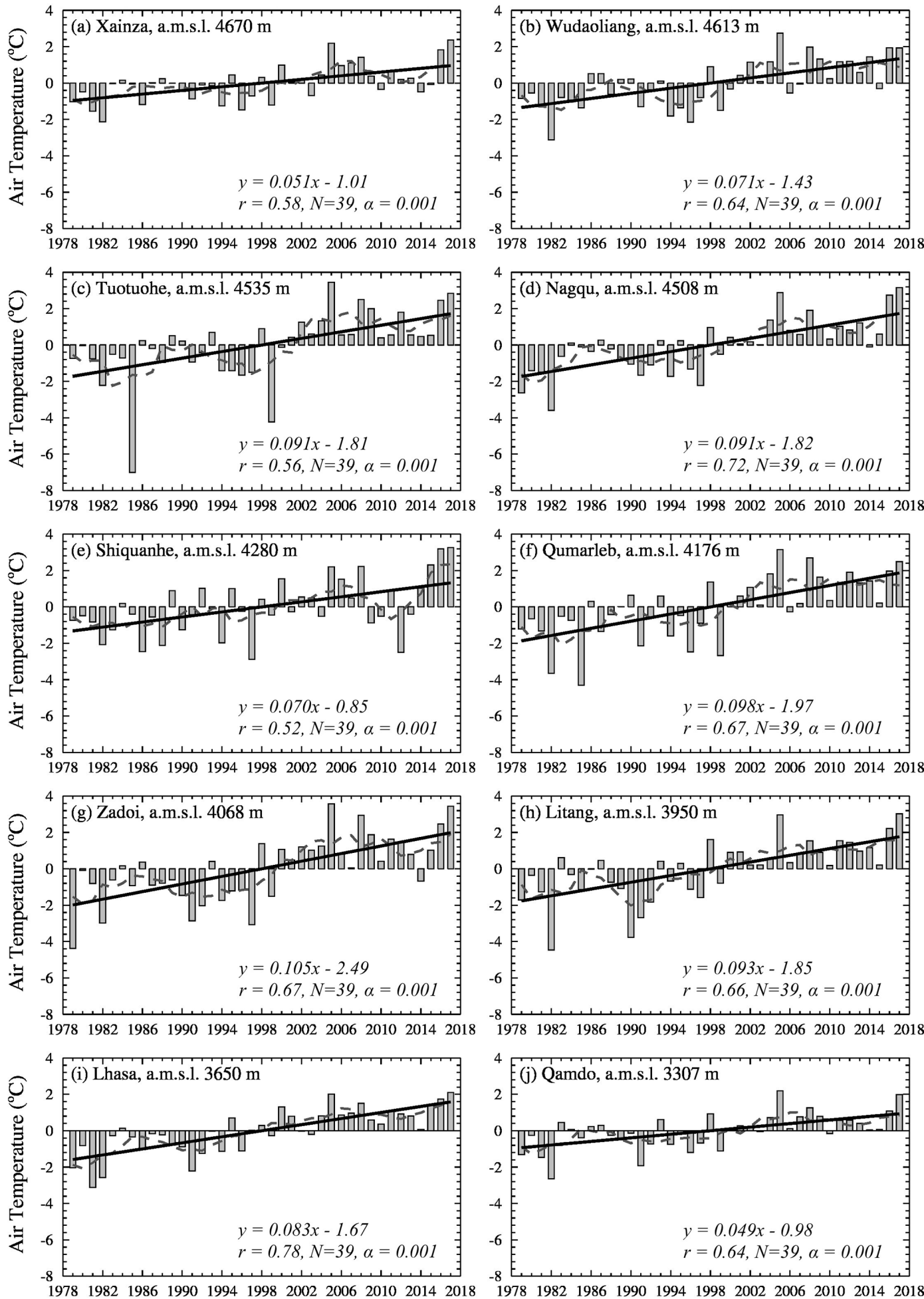

Figure 2. Trends of observational winter (December-January-February) mean temperature anomaly recorded by 10 weather stations over the Tibetan Plateau during the last 4 decades (1979-2017). 


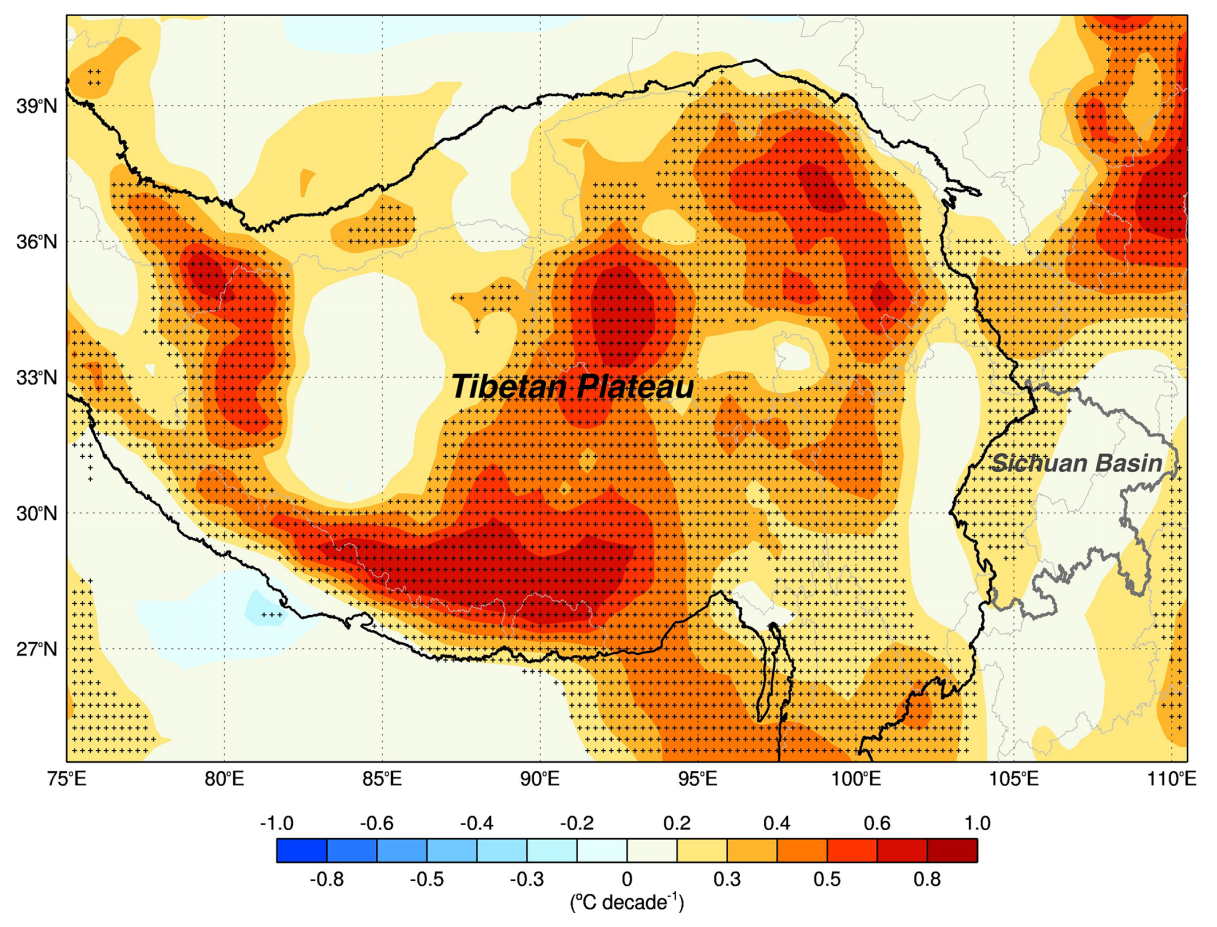

Figure 3. Trends of ERA-Interim reanalysis winter mean temperature over the Tibetan Plateau from 1979 to 2017 . The dotted regions show statistical significance with $95 \%$ confidence level $(p$ value $<0.05)$ from the Student $t$ test.

wind speed is obviously higher, with an average of $2.0 \mathrm{~m} \mathrm{~s}^{-1}$ (Fig. S4c). The observed prevailing wind is northerly while the simulated prevailing wind is easterly (Fig. S4d). Figure S5a in the Supplement shows that $\mathrm{PM}_{2.5}$ concentration is lower in the north towards the Sichuan Basin while higher towards the east to the basin. Therefore, the overestimated $\mathrm{PM}_{2.5}$ concentration is mainly caused by the departure of winds, which results in a false transport from the east to the basin. This is also shown by the overestimation of $\mathrm{CO}$ concentration because the observed northerly wind is not well simulated due to the complicated topography.

\subsection{Change in winter $\mathbf{P M}_{2.5}$ concentration over the basin}

To examine impacts of a warming plateau on $\mathrm{PM}_{2.5}$ concentration in winter in the basin, we set three levels of temperature increase of $0.5,1.0$ and $2.0^{\circ} \mathrm{C}$ over the plateau. Time series of $\mathrm{PM}_{2.5}$ concentrations in these simulations (with and without the warming over the plateau) are respectively calculated. The results show that $\mathrm{PM}_{2.5}$ concentration in the basin is significantly reduced (Fig. 5). In comparison with three levels of temperature increase, the maximal reduction occurs in the case of $2{ }^{\circ} \mathrm{C}$ warming, with an average of $25.1 \mu \mathrm{g} \mathrm{m}^{-3}$ ( $p<0.001$ ). Under the circumstance of the $2{ }^{\circ} \mathrm{C}$ warming, the maximal hourly reduction reaches $84.6 \mu \mathrm{g} \mathrm{m}^{-3}$ (Fig. S6a in the Supplement) and the maximal percentage reduction is about $64.4 \%$ (Fig. S6b). We also calculate the changes in $\mathrm{PM}_{2.5}$ concentration and its percentage under the influence of the $2{ }^{\circ} \mathrm{C}$ warming on the basis of January 2018 (Fig. S7 in the Supplement), of which the result is consistent with Fig. S6, though there must inevitably be some differences in the magnitude. Interestingly, the maximal reduction always occurs while $\mathrm{PM}_{2.5}$ concentration reaches a peak value, which suggests that the impact of the warming plateau is extremely significant during the period of high $\mathrm{PM}_{2.5}$ concentration. This result is similar to previous studies which also point out that extreme weather plays important roles in affecting air quality (De Sario et al., 2013; Hong et al., 2019; Tsangari et al., 2016; Zhang et al., 2016). That is to say, the impact of the warming plateau on air quality is apt to be amplified in extremely high $\mathrm{PM}_{2.5}$ concentrations.

To better understand the impact of a warming plateau on $\mathrm{PM}_{2.5}$ concentration, we also calculate changes in $\mathrm{PM}_{2.5}$ chemical composition in the basin. Both primary and secondary aerosols in $\mathrm{PM}_{2.5}$ decrease more significantly with an increase in temperature increment (Fig. 6), except for the nitrate due to its competition for ammonia with sulfate (Feng et al., 2018). As a result, the more sulfate that is reduced under the case of the $2{ }^{\circ} \mathrm{C}$ warming, the less nitrate that is reduced. As shown in Fig. 6, the warmer the plateau is, the more $\mathrm{PM}_{2.5}$ concentration and its chemical composition in the basin decrease, suggesting that a warming plateau has increasing implications for air quality in the basin. Here we show that the maximal impact of the plateau under the case of the $2{ }^{\circ} \mathrm{C}$ warming, in which secondary aerosol reduces by $19.7 \mu \mathrm{g} \mathrm{m}^{-3}$, accounting for $78.5 \%$ of the total 

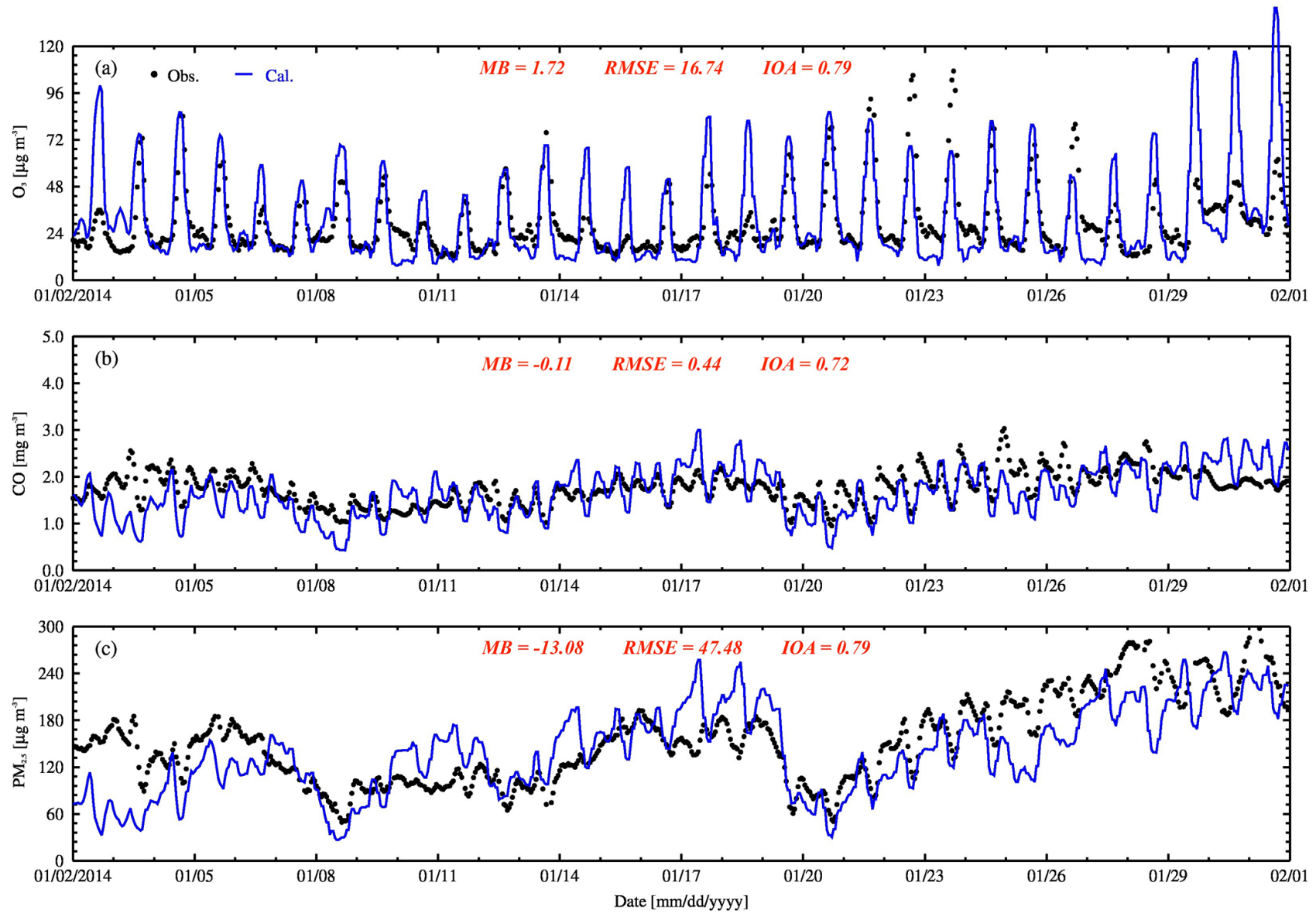

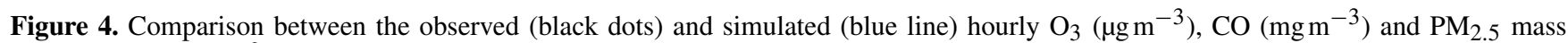
concentration $\left(\mu \mathrm{g} \mathrm{m}^{-3}\right)$ over the Sichuan Basin in January 2014.

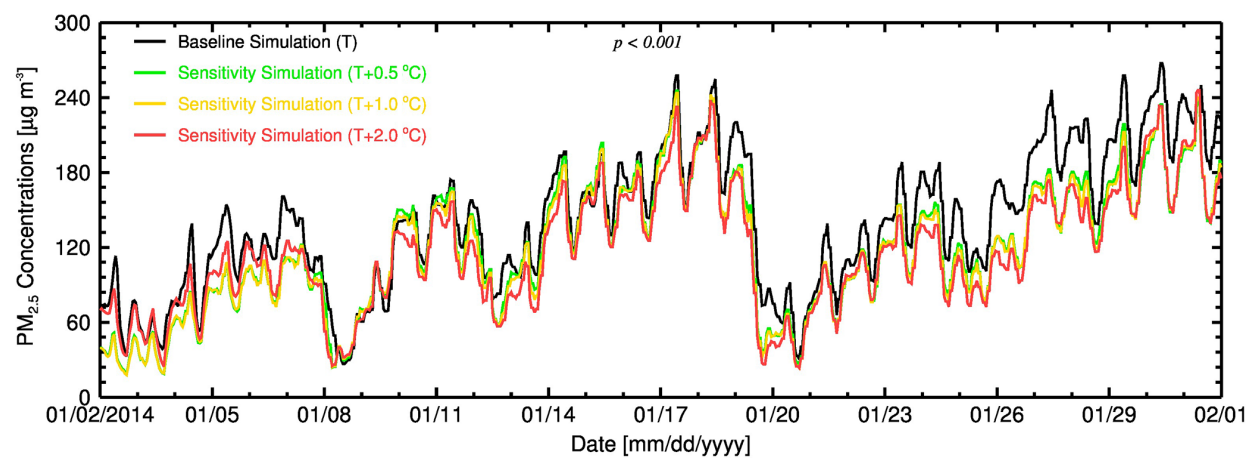

Figure 5. Time series of $\mathrm{PM}_{2.5}$ concentration over the Sichuan Basin. The baseline simulation is selected in January 2014 and the sensitivity simulations in which $0.5,1.0$ and $2{ }^{\circ} \mathrm{C}$ warming occur over the Tibetan Plateau relative to the baseline simulation. The differences in $\mathrm{PM}_{2.5}$ concentrations between the baseline simulation and sensitivity simulations are significant, exceeding the $99.9 \%$ confidence level $(p<0.001)$.

reduction, is greatly larger than the reduction of primary aerosol. For example, the largest reduction is SOA, reducing from $23.2 \mu \mathrm{g} \mathrm{m}^{-3}$ in the base case to $10.8 \mu \mathrm{g} \mathrm{m}{ }^{-3}$ in the $2{ }^{\circ} \mathrm{C}$ warming case. The second reduction is sulfate (from 31.8 to $\left.28.6 \mu \mathrm{g} \mathrm{m}^{-3}\right)$. The next are nitrate and ammonium $(22.3$ and $19.1 \mu \mathrm{g} \mathrm{m}^{-3}$ in the base case and 20.2 and $17.5 \mu \mathrm{g} \mathrm{m}^{-3}$ in the
$2{ }^{\circ} \mathrm{C}$ warming case). Significance testing of the difference in every chemical composition between the baseline simulation and the $2{ }^{\circ} \mathrm{C}$ warming case is also given in Table S2 in the Supplement. The $p$ values of most chemical composition in $\mathrm{PM}_{2.5}$ are far less than 0.001 except that the $p$ value of EC is 0.0011 (Table S2), implying an extremely significant reduc- 


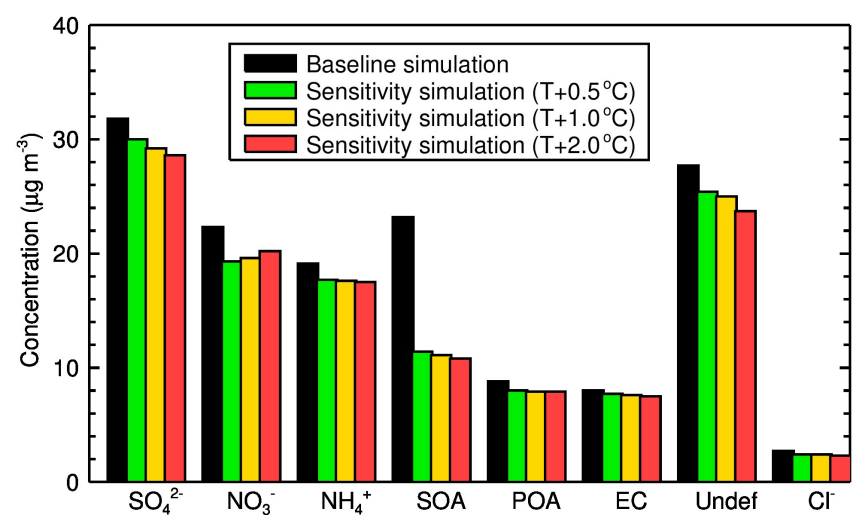

Figure 6. Comparisons of $\mathrm{PM}_{2.5}$ chemical composition in the Sichuan Basin between the baseline simulation (black) and sensitivity simulations that the plateau warms by $0.5^{\circ} \mathrm{C}$ (green), $1.0^{\circ} \mathrm{C}$ (yellow) and $2.0^{\circ} \mathrm{C}$ (red).

tion of every chemical composition in $\mathrm{PM}_{2.5}$ within the basin when the plateau warms by $2{ }^{\circ} \mathrm{C}$. Thus, we emphasize the impact of the $2{ }^{\circ} \mathrm{C}$ warming over the plateau on $\mathrm{PM}_{2.5}$ concentration in the basin in our study. Meanwhile, we analyze the case for the 2017/18 winter, in which a similar change in $\mathrm{PM}_{2.5}$ chemical composition is obtained when the plateau becomes $2{ }^{\circ} \mathrm{C}$ warmer (Fig. S8 in the Supplement).

There are also significant changes in the spatial distribution of $\mathrm{PM}_{2.5}$ concentration. Figure 7 shows the spatial distribution of changes in surface $\mathrm{PM}_{2.5}$ concentration and winds after $2{ }^{\circ} \mathrm{C}$ warming over the plateau. Apparently, there is a larger decrease in $\mathrm{PM}_{2.5}$ concentration in the whole basin, and the maximal reduction is more than $30 \mu \mathrm{g} \mathrm{m}^{-3}$. By contrast, $\mathrm{PM}_{2.5}$ concentration increases by $5-15 \mu \mathrm{g} \mathrm{m}^{-3}$ at the eastern edge of the plateau. Wind patterns show that easterly winds over the basin enhance while westerly wind over the plateau weaken (Figs. S5 and 7). Enhanced easterly winds and weakened westerly winds are both in favor of the eastto-west transport of pollutants from the basin to the plateau. We also show changes in $\mathrm{PM}_{2.5}$ concentration and winds under the cases of 0.5 and $1.0^{\circ} \mathrm{C}$ warming in January 2014 , consistent with the result of the $2{ }^{\circ} \mathrm{C}$ warming, except that the reduction of $\mathrm{PM}_{2.5}$ concentration and the change in wind speed are less (Fig. S9a and e in the Supplement). The case in January 2018 (Fig. S10a in the Supplement) is also similar to the result of the $2{ }^{\circ} \mathrm{C}$ warming.

We further compare the difference in the surface pressure between the baseline and sensitivity simulations, and we find out that surface pressure over the plateau and the basin decreases when the plateau warms (Fig. 8a and b). Over the plateau, the pressure drop has a decrease characteristic from west to east (Figs. 8c, S9b and f and S10b), which results in a decreased pressure gradient and a weakened westerly wind. While in the basin, the pressure drop is less than the plateau. This leads to an increased pressure gradient from the basin to the plateau, inducing an intensified easterly wind.
The enhanced easterly wind causes an increased transport of $\mathrm{PM}_{2.5}$ from the basin to the plateau. On the other hand, the weakened westerly wind and the enhanced easterly wind are convergent at the border between the plateau and the basin (Figs. 7, S9a and e and S10a), jointly leading to an increase in $\mathrm{PM}_{2.5}$ concentration at the eastern edge of the plateau. Additionally, northerly winds over the basin slightly enhance, conducive to diluting the air and reducing $\mathrm{PM}_{2.5}$ concentration. Both easterly wind transport and northerly wind dilution are favorable for a reduction of $\mathrm{PM}_{2.5}$ concentration in the basin. In addition to the wind effect, there are also other important factors to produce the $\mathrm{PM}_{2.5}$ reduction in the basin, such as the PBLH and RH, which will be analyzed as follows.

\subsection{Impact of PBLH on $\mathrm{PM}_{2.5}$ concentration}

Previous studies show that the PBL development plays an important role in diffusing pollutants (Miao et al., 2017; Su et al., 2018; Tie et al., 2015). Here we calculate the change in the PBLH due to the $2{ }^{\circ} \mathrm{C}$ warming over the plateau, and then we analyze the effect of the change in PBLH on $\mathrm{PM}_{2.5}$ concentration in the basin.

Our results suggest that the warming plateau plays different roles in the PBL development over the plateau and the basin. Due to the warming, the PBLH decreases in most areas of the plateau, but it increases over the basin (Figs. 9, S9c and $\mathrm{g}$, and $\mathrm{S} 10 \mathrm{c})$. The maximal rise occurs under the case of the $2{ }^{\circ} \mathrm{C}$ warming, by 50-200 $\mathrm{m}$ over the basin (Figs. 9 and S10c). As known, a shallow PBL constrains $\mathrm{PM}_{2.5}$ near the surface via suppressing vertical dispersion (Fan et al., 2011; Iversen, 1984). Conversely, a deep PBL is favorable for $\mathrm{PM}_{2.5}$ diffusion. Thus, we explore the underlying cause that leads to the difference in the PBLH in the domain. The PBLH is strongly related to the changes in vertical temperature and wind; Figs. 10, S11 and S12 in the Supplement display vertical profiles of changes in temperature and winds in the plateau and the basin. Results show that the warming causes a maximal warm layer around $1 \mathrm{~km}$ above the ground of the plateau. Noticeably, the warm layer acts as a dome covering $4.5 \mathrm{~km}$ above the Sichuan Basin (Figs. 10a, S11a and c, and S12a). Xu et al. (2017) also finds out a significant warm plume extending from the plateau to the downstream Sichuan Basin and Yangtze River Delta by use of NCEP/NCAR reanalysis data. We suggest that this is probably due to a sharp topography decrease (from $\sim 5 \mathrm{~km}$ in the plateau to $<1 \mathrm{~km}$ in the basin) which leads to a warm plume via subsidence. In the basin, there is a decrease in the temperature from the lower troposphere to $\sim 4 \mathrm{~km}$, with a maximal temperature reduction $\left(0.5-2{ }^{\circ} \mathrm{C}\right)$ located at 1.5 to $3 \mathrm{~km}$ above the ground (Figs. 10a, S11a and c, and S12a). We speculate that changes in the surface pressure can account for the maximal temperature reduction here. After the warming, surface pressure decreases in the basin (Figs. 8, S9b and f, and $\mathrm{S} 10 \mathrm{~b}$ ), which produces more convergent airflow (as shown in Figs. 7, S9a and e, and S10a). The strengthened convergent 


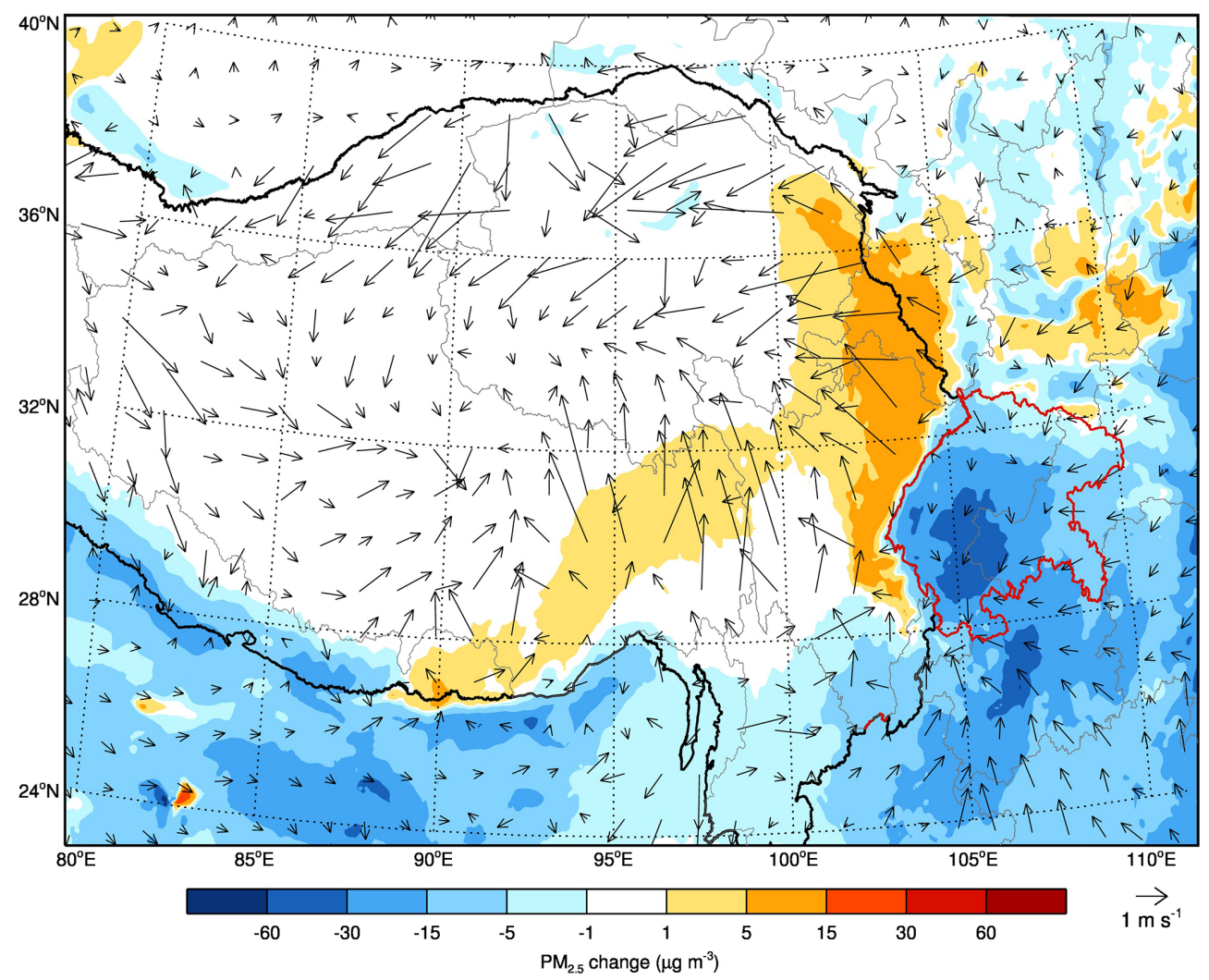

Figure 7. Difference in spatial distributions of surface $\mathrm{PM}_{2.5}$ concentration (shading) and winds (arrows) between the sensitivity simulation and baseline simulation. Negative values show $\mathrm{PM}_{2.5}$ concentration decreases and the positive values show $\mathrm{PM}_{2.5}$ concentration increases when the Tibetan Plateau warms by $2{ }^{\circ} \mathrm{C}$.

airflow induces an intensified ascending motion, conducive to a reduction of temperature in the basin. As a result, the zone where the maximal temperature drop appears overlaps with the zone with the maximal ascending motion. Furthermore, the intensified updraft increases the vertical temperature gradient and the instability in the lower troposphere of the basin, thereby causing a higher PBLH than that in the non-warming case (Figs. 10b, S11b and d, and S12b). On the contrary, the change in vertical temperature profile leads to a decreased vertical temperature gradient and increased thermal stability in the lower troposphere of the plateau, in which the PBLH decreases.

On the other hand, the convergent airflows by a weakened westerly wind over the plateau and a strengthened easterly wind in the basin trigger an ascending motion on the east side of the plateau (Figs. 10a, S11a and c, and S12a), which is also beneficial to the development of the PBLH in the basin. Consequently, the elevated PBL facilitates vertical diffusion, leading to a reduction in $\mathrm{PM}_{2.5}$ concentration over the basin.

\subsection{Effect of $\mathrm{RH}$ on $\mathrm{PM}_{2.5}$ concentration}

In addition to the PBLH, ambient RH is a key factor for secondary aerosol formation (Tie et al., 2017; Wang et al.,
2016). Previous studies indicate that aerosol hygroscopic growth cannot occur until the humidity exceeds $50 \%$ (Liu et al., 2008). When the humidity is greater than $60 \%$, hygroscopic growth factor of urban aerosol increases significantly with humidity (Liu et al., 2008).

We examine the influence of the RH change induced by a warming plateau on $\mathrm{PM}_{2.5}$ concentration in the basin. Results show that there is remarkable change in $\mathrm{RH}$ in the basin due to the warming of the plateau (Figs. 11, S9d and h, and $\mathrm{S} 10 \mathrm{~d})$. In the baseline simulation, the $\mathrm{RH}$ varies in the range of $40 \%-80 \%$ over the basin (Fig. 11a). However, the RH varies from $50 \%$ to $70 \%$ in the $2{ }^{\circ} \mathrm{C}$ warming simulation (Fig. 11b), suggesting that the basin becomes drier when the plateau is warmer.

The RH comparison between these numerical simulations reveals that the warming causes a decrease in the RH within the basin (Figs. 11c, S9d and h, and S10d). These changes in RH have critical effects on the secondary aerosol formation. As explained by Tie et al. (2017), the reduction of RH (especially during the stage of RH from $80 \%$ to $70 \%$ ) causes a significant decrease in hygroscopic growth on the aerosol surface, resulting in less water surface for producing secondary aerosol, such as sulfate and nitrate. As a result, $\mathrm{PM}_{2.5}$ concentration decreases in the basin. There are also some fin- 
(a) Baseline Simulation

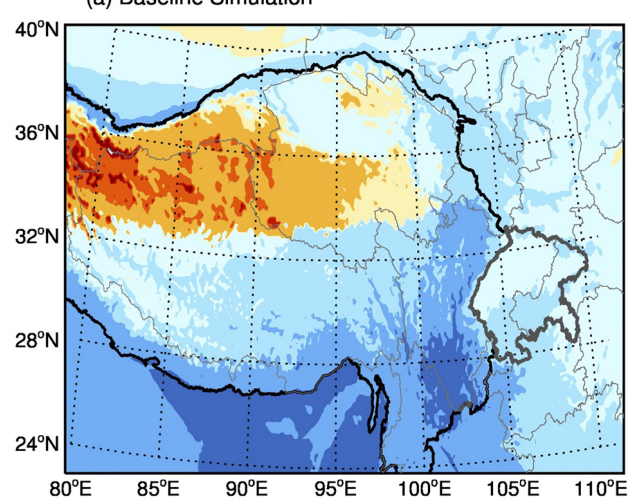

(b) Sensitivity Simulation

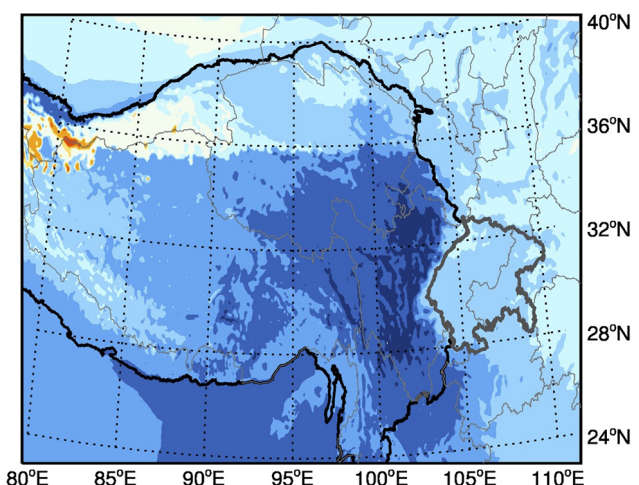

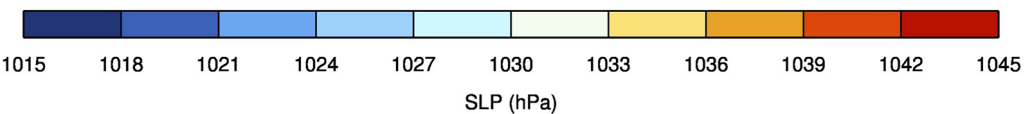

(c) Sensitivity - Baseline

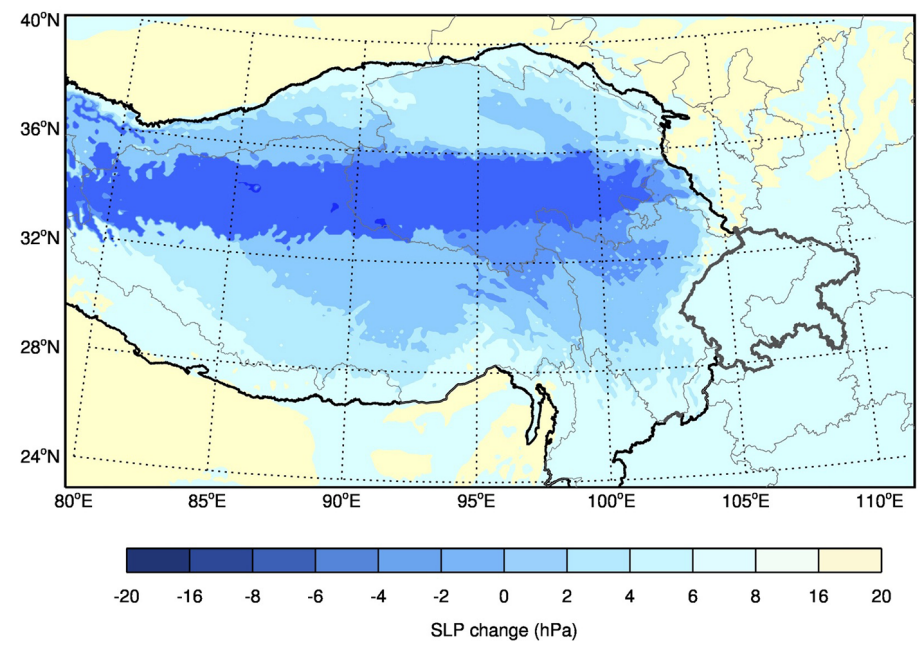

Figure 8. Comparison of spatial distributions of sea level pressure (SLP) between the (a) baseline simulation and (b) sensitivity simulation over the Tibetan Plateau and Sichuan Basin. (c) Changes in SLPs (sensitivity simulation minus baseline simulation) over the plateau and basin while the plateau warms by $2^{\circ} \mathrm{C}$.

gerprints of the RH's effect on $\mathrm{PM}_{2.5}$ concentration. Firstly, the spatial distributions of $\mathrm{RH}$ reduction and $\mathrm{PM}_{2.5}$ concentration reduction have similar patterns (Figs. 11c, 7, S9a, d, $\mathrm{e}$ and $\mathrm{h}$, and S10a and $\mathrm{d}$ ), and the region with more humidity decrease overlaps the region with more $\mathrm{PM}_{2.5}$ decreases. Secondly, as shown in Fig. 6, the changes in $\mathrm{PM}_{2.5}$ compositions indicate that the reduced $\mathrm{PM}_{2.5}$ concentration is mainly caused by the decrease in secondary aerosol concentration. Therefore, the RH change also plays an important role in $\mathrm{PM}_{2.5}$ concentration in the basin.

\section{Conclusions}

ERA-Interim reanalysis data and observation records at 10 weather stations show that the Tibetan Plateau has significantly warmed during the past 4 decades (1979-2017), par- ticularly in winter. The temperature increase rate is 0.5 to $1.0^{\circ} \mathrm{C}$ per decade in winter, approximately twice as much as the increase rate of annual mean temperature. In the last 5 years (2013-2017), the central plateau has been significantly warming with an increase rate of $1.0^{\circ} \mathrm{Cyr}^{-1}$, encompassing the warming rate during the entire 40 years. Rapid warming has caused the winter temperature to increase by an average of $2{ }^{\circ} \mathrm{C}$ over the entire plateau from 2013 to 2017 .

The WRF-Chem model is used to assess the impact of a warming plateau on air quality over the downstream Sichuan Basin. The most significant impact of the plateau on $\mathrm{PM}_{2.5}$ concentration in the basin occurs under the case of the $2{ }^{\circ} \mathrm{C}$ warming. Through an enhanced horizontal transport, a reduced RH and an increased PBLH, the warming plateau significantly reduces $\mathrm{PM}_{2.5}$ concentration in the basin. A larger pressure gradient from the basin to the plateau is favorable for an east-to-west transport for pollutants within the basin. 


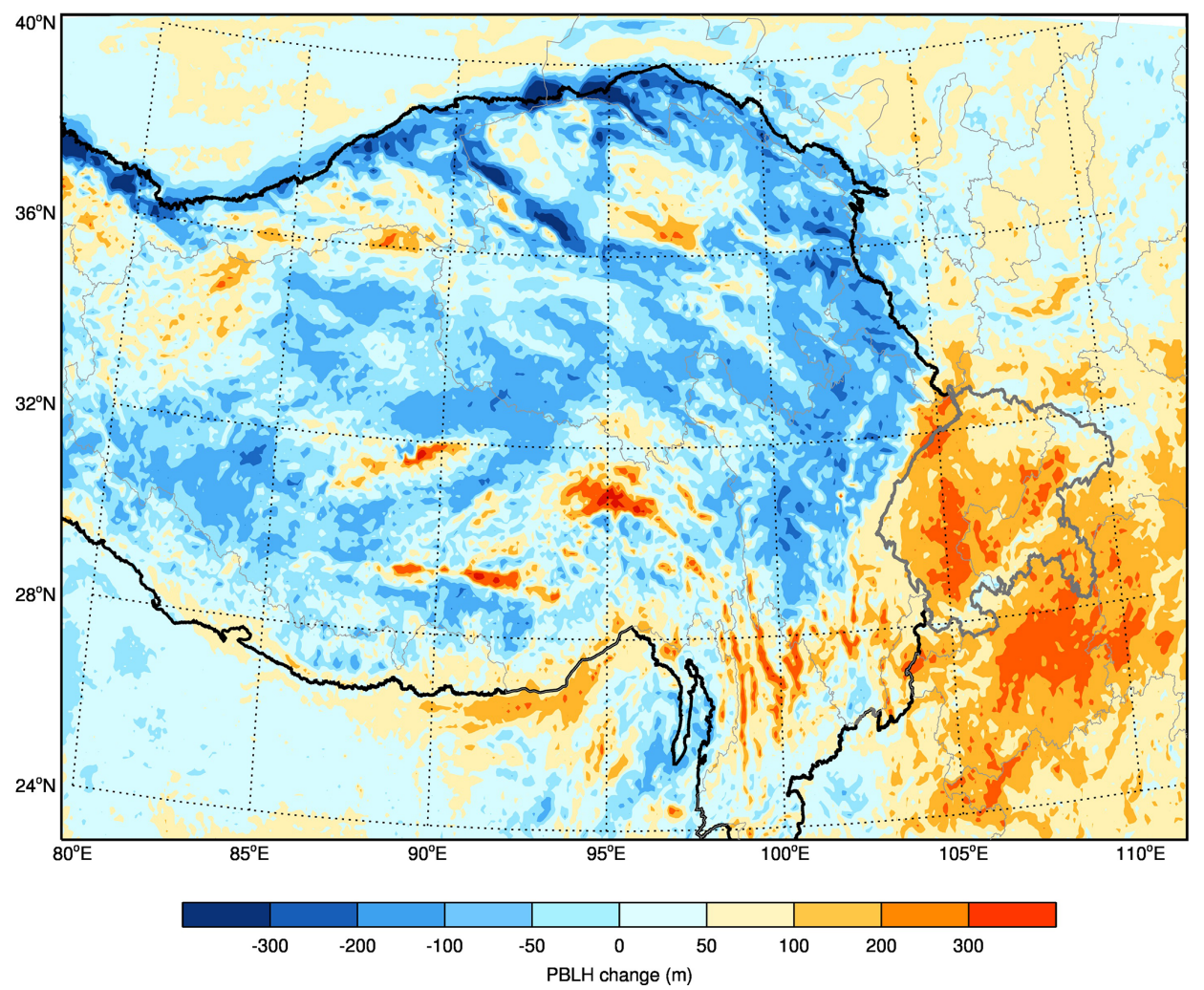

Figure 9. Spatial change in the PBL height induced by $2{ }^{\circ} \mathrm{C}$ warming over the Tibetan Plateau. The positive values show the PBL height increases while the negative values show the PBL height decreases.

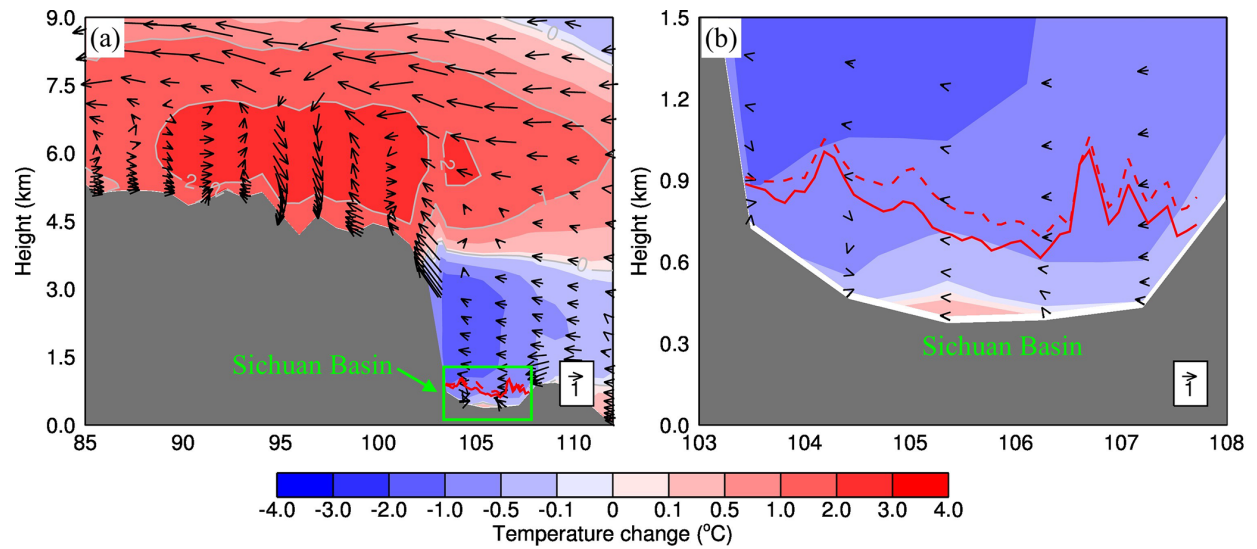

Figure 10. Vertical profiles of changes in temperature (shading and gray contour) and winds (arrows) along $30^{\circ} \mathrm{N}$ in January 2014 . The gray shaded area presents topography. The green box shows the Sichuan Basin, and the red solid (baseline simulation) and dashed (sensitivity simulation) lines show the PBL height. (a) The Tibetan Plateau and Sichuan Basin; (b) the Sichuan Basin.

A lower ambient RH decreases aerosol hygroscopic growth, which weakens secondary aerosol formation and leads to a significant reduction in secondary aerosol concentration. Moreover, the warming induces an increase in vertical temperature gradient over the basin, strengthening turbulence mixing and elevating PBLH. The elevated PBLH is favorable for vertical diffusion that causes a reduction of $\mathrm{PM}_{2.5}$ in the basin. Additionally, the uplift effect by an enhanced ascending motion at the eastern edge of the plateau also contributes to $\mathrm{PM}_{2.5}$ reduction within the basin.

In summary, the warming over the plateau in the last 5 years comprehensively induces a rising PBLH and a drying ambient air over the basin, which greatly reduces $\mathrm{PM}_{2.5}$ secondary compositions. On average, $\mathrm{PM}_{2.5}$ concentration 
(a) Baseline Simulation

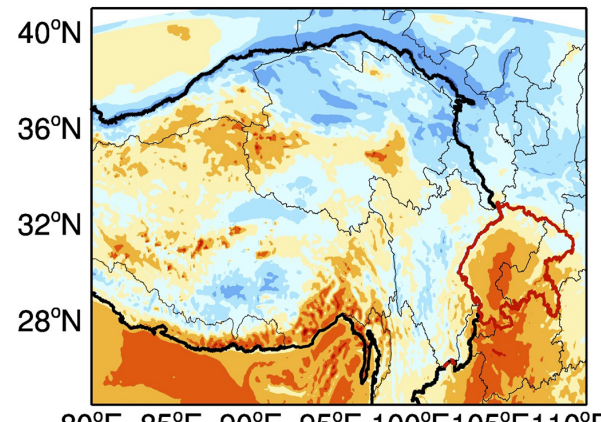

(b) Sensitivity Simulation

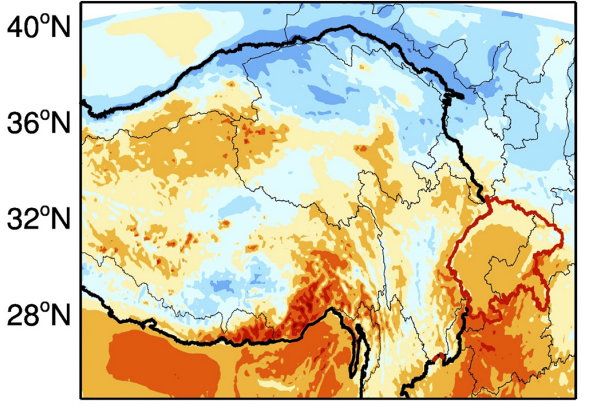

$80^{\circ} \mathrm{E} 85^{\circ} \mathrm{E} 90^{\circ} \mathrm{E} 95^{\circ} \mathrm{E} 100^{\circ} \mathrm{E} 105^{\circ} \mathrm{E} 110^{\circ} \mathrm{E}$

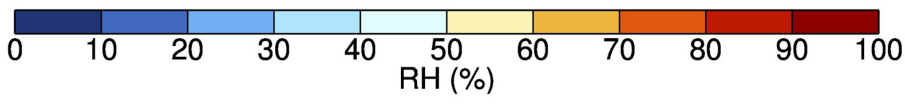

(c) Sensitivity - Baseline

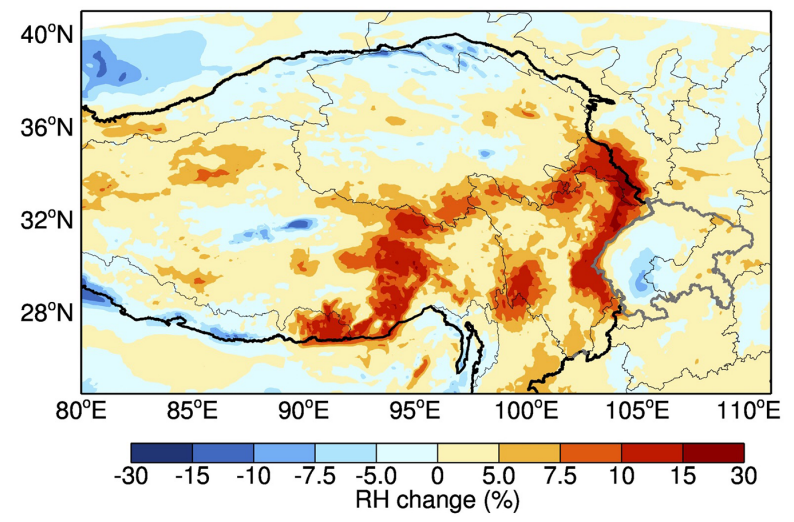

Figure 11. Comparison of spatial distributions of RH between the (a) baseline simulation and (b) sensitivity simulation over the Tibetan Plateau and Sichuan Basin. (c) Similar to Fig. 9, but for RH spatial changes when the plateau warms by $2{ }^{\circ} \mathrm{C}$, and the positive values show the RH increases while the negative values shows the RH decreases.

reduces by $25.1 \mu \mathrm{g} \mathrm{m}^{-3}$ on the basis of the 2013/14 winter, of which the primary and secondary aerosols decrease by 5.4 and $19.7 \mu \mathrm{g} \mathrm{m}^{-3}$, respectively. Here we need to clarify that our model domain may be a little small to comprehensively account for the atmospheric circulation pattern related to the Tibetan Plateau and the subsequent impact on air quality in the Sichuan Basin, though the domain covers the plateau and the basin. We notice that the basin is close to the eastern boundary of the domain, in which local circulation might be influenced by the lateral condition. Therefore, as the plateau is likely to continue warming, in-depth understanding of climate change on the Tibetan Plateau and longterm $\mathrm{PM}_{2.5}$ measurements are required to validate the impact of the warming plateau on air quality on a larger spatial scale.

Data availability. The data used in this study are available from the corresponding author upon request (tiexx@ieecas.cn).
Supplement. The supplement related to this article is available online at: https://doi.org/10.5194/acp-20-14873-2020-supplement.

Author contributions. XT designed the research and revised the final paper. SZ performed research and wrote the paper. XT and SZ provided financial support. TF validated the model, modified the chart code and reviewed the paper. ZW collected and analyzed the weather station data.

Competing interests. The authors declare that they have no conflict of interest.

Acknowledgements. We would like to acknowledge the European Center for Medium-Range Weather Forecasts (ERA-Interim) for reanalysis data which are freely obtained following registration on the website http://apps.ecmwf.int/datasets/ (last access: 1 December 2020). Ambient weather station observations are obtained from the National Oceanic and Atmospheric Administration (NOAA), http://gis.ncdc.noaa.gov/map/viewer/\#app=clim\& 
$\mathrm{cfg}=$ cdo\& theme $=$ hourly\&layers $=1 \&$ node $=$ gis (last access: 1 December 2020). The hourly ambient surface $\mathrm{O}_{3}, \mathrm{CO}$ and $\mathrm{PM}_{2.5}$ mass concentrations are released in real time by the Ministry of Environmental Protection, China on the website http://www. aqistudy.cn/ (last access: 1 December 2020), freely downloaded from http://106.37.208.233:20035/ (last access: 1 December 2020). The MEIC-2012 (Multi-resolution Emission Inventory for China) anthropogenic emission inventory is available on the website, http: //www.meicmodel.org (last access: 1 December 2020). The authors also thank the anonymous reviewers for their helpful comments and suggestions.

Financial support. This research has been supported by the National Natural Science Foundation of China (grant nos. 41430424, 41730108, and 41807307) and the West Light Foundation of the Chinese Academy of Sciences (grant no. XAB2016B04).

Review statement. This paper was edited by Xiaohong Liu and reviewed by three anonymous referees.

\section{References}

Bei, N., Li, G., Huang, R.-J., Cao, J., Meng, N., Feng, T., Liu, S., Zhang, T., Zhang, Q., and Molina, L. T.: Typical synoptic situations and their impacts on the wintertime air pollution in the Guanzhong basin, China, Atmos. Chem. Phys., 16, 7373-7387, https://doi.org/10.5194/acp-16-7373-2016, 2016.

Bei, N., Zhao, L., Xiao, B., Meng, N., and Feng, T.: Impacts of local circulations on the wintertime air pollution in the Guanzhong Basin, China, Sci. Total Environ., 592, 373-390, https://doi.org/10.1016/j.scitotenv.2017.02.151, 2017.

Binkowski, F. S.: Models-3 Community Multiscale Air Quality (CMAQ) model aerosol component 1. Model description, J. Geophys. Res., 108, 2981, https://doi.org/10.1029/2001JD001409, 2003.

Cai, W., Li, K., Liao, H., Wang, H., and Wu, L.: Weather conditions conducive to Beijing severe haze more frequent under climate change, Nat. Clim. Change, 7, 257-262, https://doi.org/10.1038/nclimate3249, 2017.

Chen, F. and Dudhia, J.: Coupling an Advanced Land SurfaceHydrology Model with the Penn State-NCAR MM5 Modeling System. Part I: Model Implementation and Sensitivity, Mon. Weather Rev., 129, 569-585, https://doi.org/10.1175/15200493(2001)129<0569:CAALSH>2.0.CO;2, 2001.

De Sario, M., Katsouyanni, K., and Michelozzi, P.: Climate change, extreme weather events, air pollution and respiratory health in Europe, Eur. Respir. J., 42, 826-843, https://doi.org/10.1183/09031936.00074712, 2013.

Duan, A., Wu, G., Liu, Y., Ma, Y., and Zhao, P.: Weather and climate effects of the Tibetan Plateau, Adv. Atmos. Sci., 29, 978-992, https://doi.org/10.1007/s00376-012-1220-y, 2012.

Dudhia, J.: Numerical Study of Convection Observed during the Winter Monsoon Experiment Using a Mesoscale Two-Dimensional Model, J. Atmos. Sci., 46, 3077-3107, https://doi.org/10.1175/15200469(1989)046<3077:NSOCOD>2.0.CO;2, 1989.
Emmons, L. K., Walters, S., Hess, P. G., Lamarque, J.-F., Pfister, G. G., Fillmore, D., Granier, C., Guenther, A., Kinnison, D., Laepple, T., Orlando, J., Tie, X., Tyndall, G., Wiedinmyer, C., Baughcum, S. L., and Kloster, S.: Description and evaluation of the Model for Ozone and Related chemical Tracers, version 4 (MOZART-4), Geosci. Model Dev., 3, 43-67, https://doi.org/10.5194/gmd-3-43-2010, 2010.

Fan, S. J., Fan, Q., Yu, W., Luo, X. Y., Wang, B. M., Song, L. L., and Leong, K. L.: Atmospheric boundary layer characteristics over the Pearl River Delta, China, during the summer of 2006: measurement and model results, Atmos. Chem. Phys., 11, 62976310, https://doi.org/10.5194/acp-11-6297-2011, 2011.

Feng, T., Li, G., Cao, J., Bei, N., Shen, Z., Zhou, W., Liu, S., Zhang, T., Wang, Y., Huang, R.-J., Tie, X., and Molina, L. T.: Simulations of organic aerosol concentrations during springtime in the Guanzhong Basin, China, Atmos. Chem. Phys., 16, 1004510061, https://doi.org/10.5194/acp-16-10045-2016, 2016.

Feng, T., Bei, N., Zhao, S., Wu, J., Li, X., Zhang, T., Cao, J., Zhou, W., and Li, G.: Wintertime nitrate formation during haze days in the Guanzhong basin, China: A case study, Environ. Pollut. B, 243, 1057-1067, https://doi.org/10.1016/j.envpol.2018.09.069, 2018.

Grell, G. A., Peckham, S. E., Schmitz, R., McKeen, S. A., Frost, G., Skamarock, W. C., and Eder, B.: Fully coupled "online" chemistry within the WRF model, Atmos. Environ., 39, 6957-6975, https://doi.org/10.1016/j.atmosenv.2005.04.027, 2005.

Guenther, A., Karl, T., Harley, P., Wiedinmyer, C., Palmer, P. I., and Geron, C.: Estimates of global terrestrial isoprene emissions using MEGAN (Model of Emissions of Gases and Aerosols from Nature), Atmos. Chem. Phys., 6, 3181-3210, https://doi.org/10.5194/acp-6-3181-2006, 2006.

Hong, C., Zhang, Q., Zhang, Y., Davis, S. J., Tong, D., Zheng, Y., Liu, Z., Guan, D., He, K., and Schellnhuber, H. J.: Impacts of climate change on future air quality and human health in China, P. Natl. Acad. Sci. USA, 116, 17193-17200, https://doi.org/10.1073/pnas.1812881116, 2019.

Hong, S.-Y. and Lim, J.-O. J.: The WRF single-moment 6-class microphysics scheme (WSM6), J. Korean Meteor. Soc., 42, 129 $151,2006$.

Hua, M.: Analysis and simulation study on the influence of heat condition over Qinghai-Xizang Plateau on climate over SouthWest China, Plateau Meteorology, 22, 152-156, 2017.

Iversen, T.: On the atmospheric transport of pollution to the Arctic, Geophys. Res. Lett., 11, 457-460, https://doi.org/10.1029/GL011i005p00457, 1984.

Janjicì, Z. I.: Nonsingular implementation of the Mellor-Yamada level 2.5 scheme in the NCEP meso model, NCEP Office Note no. 437, NOAA Science Center, 2002.

Kuang, X. and Jiao, J. J.: Review on climate change on the Tibetan Plateau during the last half century, J. Geophys. Res., 121, 39794007, https://doi.org/10.1002/2015JD024728, 2016.

Li, G., Lei, W., Zavala, M., Volkamer, R., Dusanter, S., Stevens, P., and Molina, L. T.: Impacts of HONO sources on the photochemistry in Mexico City during the MCMA2006/MILAGO Campaign, Atmos. Chem. Phys., 10, 6551-6567, https://doi.org/10.5194/acp-10-6551-2010, 2010.

Li, G., Bei, N., Tie, X., and Molina, L. T.: Aerosol effects on the photochemistry in Mexico City during MCMA- 
2006/MILAGRO campaign, Atmos. Chem. Phys., 11, 51695182, https://doi.org/10.5194/acp-11-5169-2011, 2011a.

Li, G., Zavala, M., Lei, W., Tsimpidi, A. P., Karydis, V. A., Pandis, S. N., Canagaratna, M. R., and Molina, L. T.: Simulations of organic aerosol concentrations in Mexico City using the WRF-CHEM model during the MCMA2006/MILAGRO campaign, Atmos. Chem. Phys., 11, 37893809, https://doi.org/10.5194/acp-11-3789-2011, 2011 b.

Li, G., Bei, N., Cao, J., Huang, R., Wu, J., Feng, T., Wang, Y., Liu, S., Zhang, Q., Tie, X., and Molina, L. T.: A possible pathway for rapid growth of sulfate during haze days in China, Atmos. Chem. Phys., 17, 3301-3316, https://doi.org/10.5194/acp17-3301-2017, 2017.

Li, M., Zhang, Q., Kurokawa, J.-I., Woo, J.-H., He, K., Lu, Z., Ohara, T., Song, Y., Streets, D. G., Carmichael, G. R., Cheng, Y., Hong, C., Huo, H., Jiang, X., Kang, S., Liu, F., Su, H., and Zheng, B.: MIX: a mosaic Asian anthropogenic emission inventory under the international collaboration framework of the MICS-Asia and HTAP, Atmos. Chem. Phys., 17, 935-963, https://doi.org/10.5194/acp-17-935-2017, 2017.

Liu, X. and Chen, B.: Climatic warming in the Tibetan Plateau during recent decades, Int. J. Climatol., 20, 1729-1742, 2000.

Liu, X., Cheng, Y., Zhang, Y., Jung, J., Sugimoto, N., Chang, S.-Y., Kim, Y. J., Fan, S., and Zeng, L.: Influences of relative humidity and particle chemical composition on aerosol scattering properties during the 2006 PRD campaign, Atmos. Environ., 42, 15251536, https://doi.org/10.1016/j.atmosenv.2007.10.077, 2008.

Miao, Y., Guo, J., Liu, S., Liu, H., Li, Z., Zhang, W., and Zhai, P.: Classification of summertime synoptic patterns in Beijing and their associations with boundary layer structure affecting aerosol pollution, Atmos. Chem. Phys., 17, 3097-3110, https://doi.org/10.5194/acp-17-3097-2017, 2017.

Qiao, X., Guo, H., Tang, Y., Wang, P., Deng, W., Zhao, X., $\mathrm{Hu}$, J., Ying, Q., and Zhang, H.: Local and regional contributions to fine particulate matter in the 18 cities of Sichuan Basin, southwestern China, Atmos. Chem. Phys., 19, 57915803, https://doi.org/10.5194/acp-19-5791-2019, 2019.

Rangwala, I., Miller, J. R., and Xu, M.: Warming in the Tibetan Plateau: Possible influences of the changes in surface water vapor, Geophys. Res. Lett., 36, 5-6, https://doi.org/10.1029/2009GL037245, 2009.

$\mathrm{Su}, \mathrm{T}$., Li, Z., and Kahn, R.: Relationships between the planetary boundary layer height and surface pollutants derived from lidar observations over China: regional pattern and influencing factors, Atmos. Chem. Phys., 18, 15921-15935, https://doi.org/10.5194/acp-18-15921-2018, 2018.

Tao, J., Zhang, L., Cao, J., and Zhang, R.: A review of current knowledge concerning $\mathrm{PM}_{2.5}$ chemical composition, aerosol optical properties and their relationships across China, Atmos. Chem. Phys., 17, 9485-9518, https://doi.org/10.5194/acp-179485-2017, 2017.

Tie, X., Madronich, S., Walters, S., Zhang, R., Rasch, P., and Collins, W.: Effect of clouds on photolysis and oxidants in the troposphere, J. Geophys. Res., 108, 4642, https://doi.org/10.1029/2003JD003659, 2003.

Tie, X., Sasha, M., Stacy, W., David, E., Paul, G., Natalie, M., Renyi, Z., Lou, C., and Guy, B.: Assessment of the global impact of aerosols on tropospheric oxidants, J. Geophys. Res., 110, D03204, https://doi.org/10.1029/2004JD005359, 2005.
Tie, X., Madronich, S., Li, G., Ying, Z., Zhang, R., Garcia, A. R., Lee-Taylor, J., and Liu, Y.: Characterizations of chemical oxidants in Mexico City: A regional chemical dynamical model (WRF-Chem) study, Atmos. Environ., 41, 1989-2008, https://doi.org/10.1016/j.atmosenv.2006.10.053, 2007.

Tie, X., Madronich, S., Li, G., Ying, Z., Weinheimer, A., Apel, E., and Campos, T.: Simulation of Mexico City plumes during the MIRAGE-Mex field campaign using the WRF-Chem model, Atmos. Chem. Phys., 9, 4621-4638, https://doi.org/10.5194/acp-94621-2009, 2009.

Tie, X., Zhang, Q., He, H., Cao, J., Han, S., Gao, Y., Li, X., and Jia, X. C.: A budget analysis of the formation of haze in Beijing, Atmos. Environ., 100, 25-36, https://doi.org/10.1016/j.atmosenv.2014.10.038, 2015.

Tie, X., Huang, R.-J., Cao, J., Zhang, Q., Cheng, Y., Su, H., Di Chang, schl, U. P. X., Hoffmann, T., Dusek, U., Li, G., Worsnop, D. R., and Dowd, C. D. O. X.: Severe Pollution in China Amplified by Atmospheric Moisture, Sci. Rep., 7, 15760, https://doi.org/10.1038/s41598-017-15909-1, 2017.

Tsangari, H., Paschalidou, A. K., Kassomenos, A. P., Vardoulakis, S., Heaviside, C., Georgiou, K. E., and Yamasaki, E. N.: Extreme weather and air pollution effects on cardiovascular and respiratory hospital admissions in Cyprus, Sci. Total Environ., 542, 247-253, https://doi.org/10.1016/j.scitotenv.2015.10.106, 2016.

Wang, G., Zhang, R., Gomez, M. E., Yang, L., Levy Zamora, M., Hu, M., Lin, Y., Peng, J., Guo, S., Meng, J., Li, J., Cheng, C., Hu, T., Ren, Y., Wang, Y., Gao, J., Cao, J., An, Z., Zhou, W., Li, G., Wang, J., Tian, P., Marrero-Ortiz, W., Secrest, J., Du, Z., Zheng, J., Shang, D., Zeng, L., Shao, M., Wang, W., Huang, Y., Wang, Y., Zhu, Y., Li, Y., Hu, J., Pan, B., Cai, L., Cheng, Y., Ji, Y., Zhang, F., Rosenfeld, D., Liss, P. S., Duce, R. A., Kolb, C. E., and Molina, M. J.: Persistent sulfate formation from London Fog to Chinese haze, P. Natl. Acad. Sci. USA, 113, 13630-13635, https://doi.org/10.1073/pnas.1616540113, 2016.

Wang, H., Tian, M., Chen, Y., Shi, G., Liu, Y., Yang, F., Zhang, L., Deng, L., Yu, J., Peng, C., and Cao, X.: Seasonal characteristics, formation mechanisms and source origins of $\mathrm{PM}_{2.5}$ in two megacities in Sichuan Basin, China, Atmos. Chem. Phys., 18, 865-881, https://doi.org/10.5194/acp-18-865-2018, 2018.

Wesely, M. L.: Parameterization of surface resistances to gaseous dry deposition in regional-scale numerical models, Atmos. Environ., 23, 1293-1304, https://doi.org/10.1016/00046981(89)90153-4, 1989.

Xu, J., Chang, L., Yan, F., and He, J.: Role of climate anomalies on decadal variation in the occurrence of wintertime haze in the Yangtze River Delta, China, Sci. Total Environ., 599-600, 918925, https://doi.org/10.1016/j.scitotenv.2017.05.015, 2017.

Xu, X., Zhao, T., Liu, F., Gong, S. L., Kristovich, D., Lu, C., Guo, Y., Cheng, X., Wang, Y., and Ding, G.: Climate modulation of the Tibetan Plateau on haze in China, Atmos. Chem. Phys., 16, 1365-1375, https://doi.org/10.5194/acp-16-1365-2016, 2016.

Yang, F., Tan, J., Zhao, Q., Du, Z., He, K., Ma, Y., Duan, F., Chen, G., and Zhao, Q.: Characteristics of $\mathrm{PM}_{2.5}$ speciation in representative megacities and across China, Atmos. Chem. Phys., 11, 5207-5219, https://doi.org/10.5194/acp-11-5207-2011, 2011.

Zhang, H., Wang, Y., Park, T.-W., and Deng, Y.: Quantifying the relationship between extreme air pollution events 
and extreme weather events, Atmos. Res., 188, 64-79, https://doi.org/10.1016/j.atmosres.2016.11.010, 2016.

Zhang, Q., Streets, D. G., Carmichael, G. R., He, K. B., Huo, H., Kannari, A., Klimont, Z., Park, I. S., Reddy, S., Fu, J. S., Chen, D., Duan, L., Lei, Y., Wang, L. T., and Yao, Z. L.: Asian emissions in 2006 for the NASA INTEX-B mission, Atmos. Chem. Phys., 9, 5131-5153, https://doi.org/10.5194/acp-9-5131-2009, 2009.

Zhao, P., Li, Y., Guo, X., Xu, X., Liu, Y., Tang, S., Xiao, W., Shi, C., Ma, Y., Yu, X., Liu, H., Jia, L., Chen, Y., Liu, Y., Li, J., Luo, D., Cao, Y., Zheng, X., Chen, J., Xiao, A., Yuan, F., Chen, D., Pang, Y., Hu, Z., Zhang, S., Dong, L., Hu, J., Han, S., and Zhou, X.: The Tibetan Plateau Surface-Atmosphere Coupling System and Its Weather and Climate Effects: The Third Tibetan Plateau Atmospheric Science Experiment, J. Meteorol. Res., 33, 375-399, https://doi.org/10.1007/s13351-019-8602-3, 2019.
Zhao, S., Tie, X., Cao, J., and Zhang, Q.: Impacts of mountains on black carbon aerosol under different synoptic meteorology conditions in the Guanzhong region, China, Atmos. Res., 164-165, 286-296, https://doi.org/10.1016/j.atmosres.2015.05.016, 2015.

Zhao, S., Feng, T., Tie, X., Long, X., Li, G., Cao, J., Zhou, W., and An, Z.: Impact of Climate Change on Siberian High and Wintertime Air Pollution in China in Past Two Decades, Earths Future, 6, 118-133, https://doi.org/10.1002/2017EF000682, 2018.

Zhu, Q., Shou, S., and Tang, D.: Principles and methods of weather, 4th Edn., China Meteorological Press, Beijing, 2000.

Zou, Y., Wang, Y., Zhang, Y., and Koo, J.-H.: Arctic sea ice, Eurasia snow, and extreme winter haze in China, Sci. Adv., 3, e16027519, https://doi.org/10.1126/sciadv.1602751, 2017. 